\title{
Study of the water regime dynamics of cherry in the summer period
}

\author{
Zoya Ozherelieva*, and Anna Lyakhova \\ Russian Research Institute of Fruit Crop Breeding (VNIISPK), 302530 Zhilina, Oryol, Oryol Region, \\ Russia
}

\begin{abstract}
The research was carried out on the basis of the VNIISPK Laboratory of Fruit Plant Resistance Physiology in 2019-2020. The research object was the Novella cherry variety on the clonal rootstocks of the institute selection. The purpose of this research is to study the dynamics of the water regime of the Novella variety on clonal rootstocks and to identify the most adapted scion-rootstock cherry combinations. A strong relationship was determined between the cherry leaves hydration and the average daily air temperature $(r=0.99)$. During the ripening period of the fruits of the Novella variety scion-rootstock combinations, the maximum decrease in the total water in the leaves was recorded. The water content decreased as the age of the leaves increased. The decrease in water content in the Novella scion-rootstock combinations was accompanied by an increase in the dry matter content in the leaf tissues. There was a strong relationship between the dry matter accumulation in the leaves and the average daily air temperature $(r=-0.99)$. The water deficit in the leaves depended on the hydrothermal regime of the summer period. Correlation $(\mathrm{r}$ $=0.76)$ between the leaves water deficit and the average daily air temperature, the amount of precipitation $(\mathrm{r}=-0.77)$ and the HTC $(\mathrm{r}=-$ 0.83 ). The highest water deficiency indicator in leaves was found during shoots growth and formation of the leaf apparatus in the Novella variety on clonal rootstocks. The conducted studies allowed to identify adapted scionrootstock combinations of Novella/Rubin, V-2-180, 74340, 74336, 74332, which, against the background of water content decrease and dry matter accumulation were characterized by the lowest water deficit of leaves in the summer.
\end{abstract}

\section{Introduction}

Water and temperature stresses are the main limiting factors in crop production worldwide [1-4]. The share of irrigated land in the total area of arable land and perennial plantings in the Russian Federation is only 3.6\% [5], so most of the gardens are cultivated in non-irrigated conditions and are entirely dependent on abiotic factors. The plants water regime is subject to changing during individual development, and therefore the water demand in different periods of their life is not the same. Obtaining high and stable yields is largely dependent on the influence of meteorological conditions. In the conditions of the

\footnotetext{
*Corresponding author: ozherelieva@vniispk.ru
} 
Orel region, the probability of years with intense droughts and dry winds is $20-55 \%$, and they often occur in June and July, during the active growing period and fruiting of fruit and berry crops. Varieties of fruit crops differ in their resistance to drought and high temperatures. Under the influence of drought and high temperatures, the total leaf surface decreases, the leaves turn yellow and fall off prematurely, burns and necrotic spots appear, ovaries and fruits fall off, the growth of shoots stops early [6-11], the growth of the root system is inhibited, which leads to yield decrease by 15-30\%. Low water availability and abnormally high temperatures cause changes in plant metabolism and lead to water exchange violation in plants [12]. Lack of moisture in plants affects such processes as transpiration, photosynthesis, respiration, plants enzymatic activity, growth and development, mineral substances ratio. By changing the metabolism, the lack of water affects productivity, taste of fruits, and wood density [13].

The purpose of this research is to study the dynamics of the water regime of the Novella variety on clonal rootstocks and to identify the most adapted scion-rootstock combinations in summer period.

\section{Materials and methods of research}

The research was carried out on the basis of the FSBSI VNIISPK Laboratory of Fruit Plant Resistance Physiology in 2019-2020, according to the methodological recommendations $[14,15]$. The objects of research were the Novella cherry variety growing on the clonal rootstocks of the institute's selection. The year of planting - 2011. Planting plan $-5 \times 2 \mathrm{~m}$. Spacing and trunk area are natural grassing-down.

Novella variety (Rossoshanskaya Chernaya $\times$ Vozrozhdeniye No. 1) was estacreated in the FSBSI VNIISPK in 1995. In 2001, it was accepted into the State Register and recommended for cultivation in the Central Chernozem region. High-yielding, winter-hardy variety. Average winter hardiness of flower buds. Medium drought resistance. Medium ripening period. Fruiting starts on the 4th year. The yield is $15 \mathrm{~kg} /$ tree. Multi-purpose.

Clonal rootstocks: OVP-2 (Zolushka $\times$ vishnya Maaka) is taken as control, 74324 (Lyubskaya $\times$ C. serrulata Hall \& Tolivetto), 74332 (Lyubskaya $\times$ C. lannesiana No. 2), 74336 (Lyubskaya $\times$ C. sachalinensis Edwin Müller), 74340 (Lyubskaya $\times$ C. sachalinensis Edwin Müller), Rubin (Zolushka $\times$ vishnya Maaka), V-2-180 (Vladimirskaya $\times$ VP-1)

To determine water regime parameters, leaf samples were taken in dry, hot weather, in the morning. 15 leaves of each scion-rootstock combination were collected in plastic bags. The experiment was carried out in a 3 -fold repetition. There are 5 leaves in each repetition.

The leaves were weighed to determine water content, water scarcity, and dry matter accumulation. After weighing, the leaves were placed in glasses of water for full saturation. The duration of water saturation is 24 hours. Then the leaves were weighed and laid out in metal weighting bottles and dried in a "Binder" BD23 thermostat at $+105^{\circ} \mathrm{C}$ to a constant mass. Drying time is 6 hours.

The formula for water regime parameters calculation:

1. Leaves water content in the garden, $\%$

$$
\mathrm{O}=\frac{\mathrm{m}_{1}-\mathrm{m}_{0}}{\mathrm{~m}_{1}} \times 100 \%
$$

$\mathrm{O}$ - leaves water content from the raw mass, $\%$;

$\mathrm{m}_{0}$ - weight of absolutely dry leaf batch, $\mathrm{g}$;

$\mathrm{m}_{1}$ - weight of raw leaf batch at the beginning of the experiment, $\mathrm{g}$

2. Water deficit of plant leaves in the garden, $\%$

$$
W D=\frac{\mathrm{m}_{3}-\mathrm{m}_{1}}{\mathrm{~m}_{3}-\mathrm{m}_{0}} \times 100 \%
$$


WD - water deficit, \%;

$\mathrm{m}_{0}$ - weight of absolutely dry leaf batch, $\mathrm{g}$;

$\mathrm{m}_{1}$ - weight of raw leaf batch at the beginning of the experiment, $\mathrm{g}$;

$\mathrm{m}_{3}$ - weight of leaf batch after full saturation, $\mathrm{g}$

3. Amount of dry matter in leaves, $\%$

$$
S V=\frac{\mathrm{m}_{0}}{\mathrm{~m}_{1}} \times 100 \%
$$

SV - amount of dry matter, $\%$;

$\mathrm{m}_{0}$ - weight of absolutely dry leaf batch, g;

$\mathrm{m}_{1}$ - weight of raw leaf batch at the beginning of the experiment, $\mathrm{g}$

Statistical processing of the results was carried out by the method of variance (ANOVA) and correlation analysis. The calculations were performed using the Microsoft Excel 2010 software package. Significant differences between the varieties (LSD 05$)$ were determined with a reliable probability of $95 \%$, calculating the arithmetic mean $(\mathrm{M})$ and the standard error of the mean $( \pm \mathrm{SEM})$. To determine the degree of water regime indicators alignment, the variation coefficient $(\mathrm{V})$ was calculated.

\section{Results and discussion}

Water exchange of fruit plants was studied in the works $[16,17]$, in which the most significant water regime indicators are noted: water content, water deficit, water retention capacity and water content restoration.

\subsection{Determination of water content in the leaves}

Weather conditions during the growing season have a great influence on the growth and productivity of plants [18]. The study of the water regime of the Novella variety on clonal rootstocks was carried out in years different by meteorological conditions. The analysis of weather conditions of the growing season 2019-2020 showed an uneven distribution of precipitation and temperature. June 2019 was hot and dry; the average daily air temperature was $3.7^{\circ} \mathrm{C}$ above normal and the amount of precipitation was $20.7 \mathrm{~mm}$. In July, there was a deviation of the average daily air temperature below the norm by $1.4^{\circ} \mathrm{C}$, and the amount of precipitation was $49.8 \mathrm{~mm}$ (69.2\% of the norm), in August, the HTC was closer to the longterm annual average norm (1.03). In June 2020, the average daily air temperature was $19.1^{\circ} \mathrm{C}\left(3.7^{\circ} \mathrm{C}\right.$ above normal), and the amount of precipitation was $8.7 \mathrm{~mm}$ less than normal. In July, high humidity conditions were observed $-111.6 \mathrm{~mm}$ ( $155 \%$ of the norm). August was dry: the average daily temperature was $18.1^{\circ} \mathrm{C}$, which is $0.7^{\circ} \mathrm{C}$ higher than normal. The total precipitation was $26.6 \mathrm{~mm}$ (45.9\% of the norm). Thus, in the summer period of 2019-2020, both arid and excessively wet conditions were observed (Table 1).

Table 1. Hydrothermal coefficient (HTC) in the summer period 2019-2020

\begin{tabular}{|l|c|c|c|c|c|}
\hline \multicolumn{1}{|c|}{ Years of research } & $\begin{array}{c}\text { Long-term average } \\
\text { annual norm }\end{array}$ & June & July & August & $\begin{array}{c}\text { Annual } \\
\text { average }\end{array}$ \\
\hline 2019 & \multirow{3}{*}{$1.1-1.2$} & 0.34 & 0.93 & 1.03 & 0.77 \\
\cline { 1 - 5 } 2020 & & 0.91 & 1.84 & 0.47 & 1.07 \\
\cline { 1 - 4 } $\begin{array}{l}\text { Long-term average } \\
\text { annual value }\end{array}$ & 0.63 & 1.39 & 0.75 & 0.92 \\
\hline
\end{tabular}

The study of water regime dynamics showed that the studied scion-rootstocks combinations of the Novella variety in 2019 in the period of intensive growth of shoots and leaf apparatus formation (June) the hydration level was lower by an average of $2.0 \%$ more 
than in 2020 (Figure 1) that is associated with arid conditions of the month (Table 1). In Novella, leaf water content in July (2019 and 2020), despite wetter conditions than in June, decreased on average by $5.7 \%$ and $7.7 \%$, respectively (Figure 1). This is explained by the fact that during this period there is a process of cherry fruits ripening, to which there is an intensive influx of water from leaves and other organs [19]. In addition, in July, the growth of annual cherry shoots continues. In August, further decrease was observed in total water in leaves by $4.8 \%$ (2019) and 2.6\% (2020) compared to July (Figure 1). Despite the different conditions of water availability in August, over the years of research, there is a decrease in water content in comparison with previous months, which is associated with the age-related condition of cherry leaves. M.D. Kushnirenko showed that water decrease in the leaves occurs precisely during growth of shoots, formation of fruits and natural aging of leaves [13]. Other authors also note a significant decrease in water content (by $8-14 \%$ ) of apple tree leaves in July and August [10].

As a result of statistical processing, there were no significant differences between the scion-rootstock combinations in terms of leaf water content. Over the years of research, the average level of leaf water content was recorded on clonal rootstocks in the Novella variety. The variation coefficient in June $(\mathrm{V}=2.5 \%)$, in July $(\mathrm{V}=4.8 \%)$ and in August $(\mathrm{V}=5.3 \%)$ indicates a low variability in the water content of leaf tissues in this genotype. With a range of variation in leaf water content in June from $65.3 \%$ (Novella/74324) to $72.9 \%$ (Novella/74340), in July from 51.9\% (Novella/74336) to $66.4 \%$ (Novella/Rubin) and in August from 50.4\% (Novella/74324) to 62.9\% (Novella/74332).
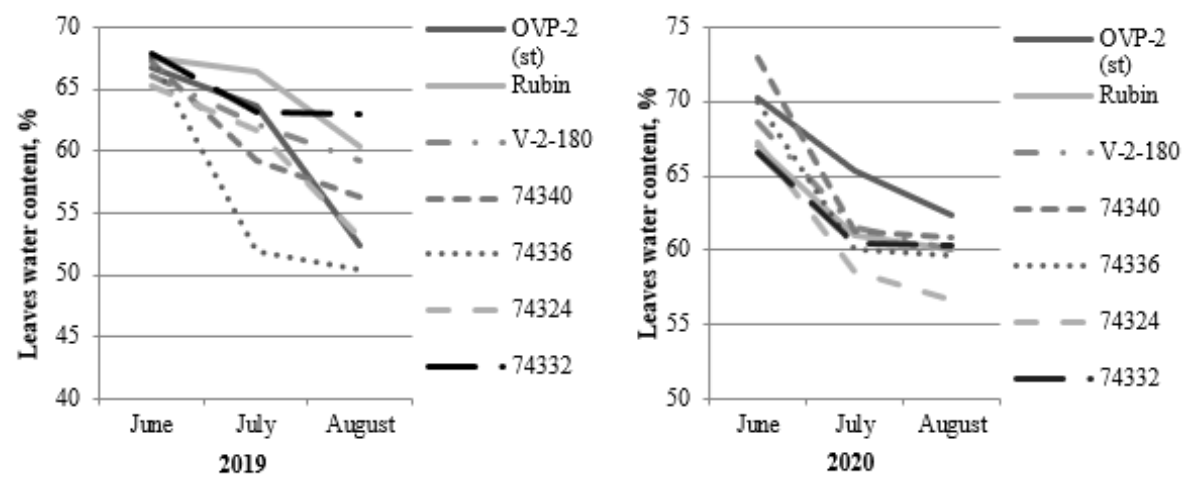

Fig. 1. Dynamics of leaves water content of the Novella cherry variety on clonal rootstocks in the summer, $\%$

\subsection{Determination of water deficit in leaves}

Since leaves water content (total water content) cannot fully characterize the water regime of the plants, the determination of water deficit of cherry leaves in the field conditions was performed. Water deficit - lack of water saturation of plant cells, resulting from the intensive water loss by the plant, which is not replenished by its absorption from the soil. In case of water deficit plant growth and productivity decline rapidly [20,21]. It is shown that decrease in water content in leaves negatively affects the growth of almonds [22, 23].

In the dry conditions of June 2019, the average water deficit in the leaves (from 11.1 to $15.2 \%$ ) was registered in the scion-rootstock combinations of the Novella variety and they did not differ significantly from each other. In July, the amount of precipitation increased, which contributed to decrease in water deficit in leaves by an average of $4.1 \%$ compared to June. At the same time, the Novella variety on the clonal rootstocks Rubin, V-2-180, 
74340,74336 noted a low water deficit (less than 10\%). The average water deficit (from 10.2 to $12.4 \%$ ) was preserved in the leaves of Novella/OVP-2, 74332, 74340. The scionrootstock combinations did not differ significantly in July for this indicator. In August, compared to July, there was an average increase in the water deficit by $2.6 \%$. In Novella/OVP-2, B-2-180, 74336, 74324, the average water deficit in the leaves was from 11.2 to $18.4 \%$. At the same time, the studied variety had a low water deficit of leaves on the Rubin, 74340, 74332 rootstocks. In August, we found significant differences in the studied parameter of water regime $\left(\mathrm{LSD}_{05}=8.2\right)$ (Figure 2).

In conditions of insufficient moisture supply in June 2020, the Novella variety on clonal rootstocks, as well as in 2019, had the average water deficit of leaves from 10.7 to $17.5 \%$. At the same time, the scion-rootstock combinations did not differ significantly in water deficit of leaves. In conditions of high humidity in July, the water deficit of leaves decreased by an average of $7.2 \%$ compared to June. As a result, the scion-rootstock combinations of cherries showed low water deficit, while no significant differences were revealed. In dry conditions of August, the water deficit in leaves decreased in Novella on the clonal rootstocks of OVP-2, V-2-180, 74336, 74332 by $1.1 \ldots 2.9 \%$. In the studied variety on the Rubin, 74340, 74324 clonal rootstocks, the water deficit in leaves remained low, although it increased (by $0.3 \ldots 2.4 \%$ ). Significant differences were found between the scion-rootstock combinations of Novella in August in terms of water deficit in leaves $\left(\mathrm{LSD}_{05}=2.9\right)$ (Figure 2).

According to the data in figure 2 the highest water deficit in plant cells of scionrootstocks combinations of the Novella variety appeared in the period of shoot growth and leaf formation (June) and at the onset of arid conditions.

The variation coefficient in June $(\mathrm{V}=10.8 \%)$, in July $(\mathrm{V}=19.6 \%)$ indicates the average variability of water deficit in leaves of the Novella variety on clonal rootstocks, and in August $(\mathrm{V}=29.4 \%)$ the variation increases.

Different reactions to weather conditions may indicate a different effect of the scion of root system development of cherry clonal rootstock. It is known that the root system has a significant impact on the state of plants water regime [24].
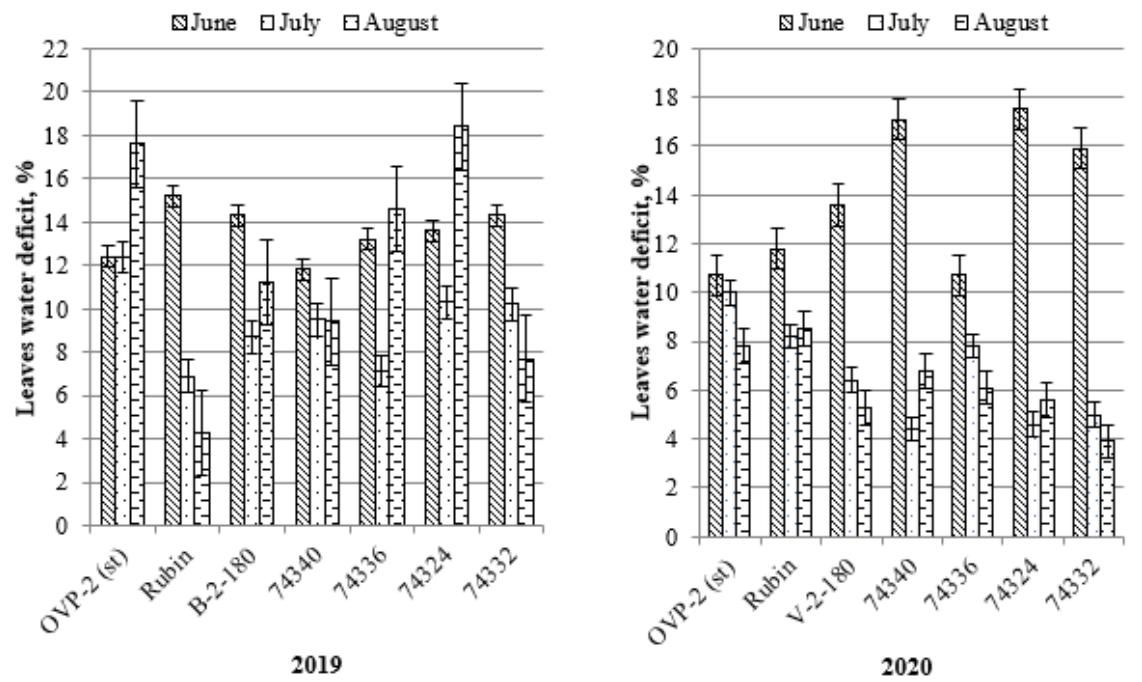

Fig. 2. Dynamics of water deficit in Novella variety leaves on clonal rootstocks in summer, \% $(\mathrm{M} \pm \mathrm{SEM})$

The conducted studies allowed to distinguish the scion-rootstock combinations 
(Novella/Rubin, V-2-180, 74340, 74336, 74332) with the lowest leaves water deficit from 9.2 to $10.0 \%$ (average for 2 years).

\subsection{Determination of dry matter content in leaves}

Dry matter content is taken as a parameter associated with the optimal water regime and characterizing the metabolic processes. The accumulation of dry matter by plants is the final result of their interaction with environmental factors and allows to judge the conditions of growth and development.

On average, the lowest amount of dry matter in the leaves of scion-rootstock combinations of the Novella variety was in June (31.1\%), the highest - in August (42.2\%). Maximum accumulation of dry matter in leaf tissues of cherries during the natural aging of leaves (August) was accompanied by decrease in water content, which is primarily due to changes in the donor-acceptor bonds between plant organs. At the same time, in July 2019 (fruit ripening period), an increase in the accumulation of dry matter in leaves of scionrootstock combinations of the Novella variety was noted by $4.7 \%$ and in 2020 by $9.7 \%$ compared to June. At the same time, in August 2019, an increase in dry matter was detected by $6.9 \%$ and in 2020 by $0.6 \%$ compared to July. The variance analysis revealed significant differences in dry matter content in the leaves of the Novella variety on clonal rootstocks in the summer (Figure 3). Other authors also note in August a greater accumulation of dry substances in leaf tissues up to $48.71 \%$ with water content decrease in apple tree [10].

If we consider the dry matter accumulation on average over the years, in conditions of dry summer 2019 dry matter accumulation $(38,6 \%$ ) was $2.8 \%$ more than in conditions of sufficient water availability in summer $2020(35,8 \%)$. Significant differences in this indicator were revealed in 2020. The variation coefficient in June $(\mathrm{V}=4.7 \%)$, in July $(\mathrm{V}=6.2 \%)$ and in August $(\mathrm{V}=7.9 \%)$ confirms that the scion-rootstock combinations of the Novella variety range a little by dry matter content in the leaves. The dry matter accumulation in the leaves varied in June from 29.7\% (Novella/74336) to $33.8 \%$ (Novella/74324), in July from 35.7\% (Novella/OVP-2) to 41.8\% (Novella/74336) and in August from 38.6\% (Novella/74332) to $47.7 \%$ (Novella/OVP-2).
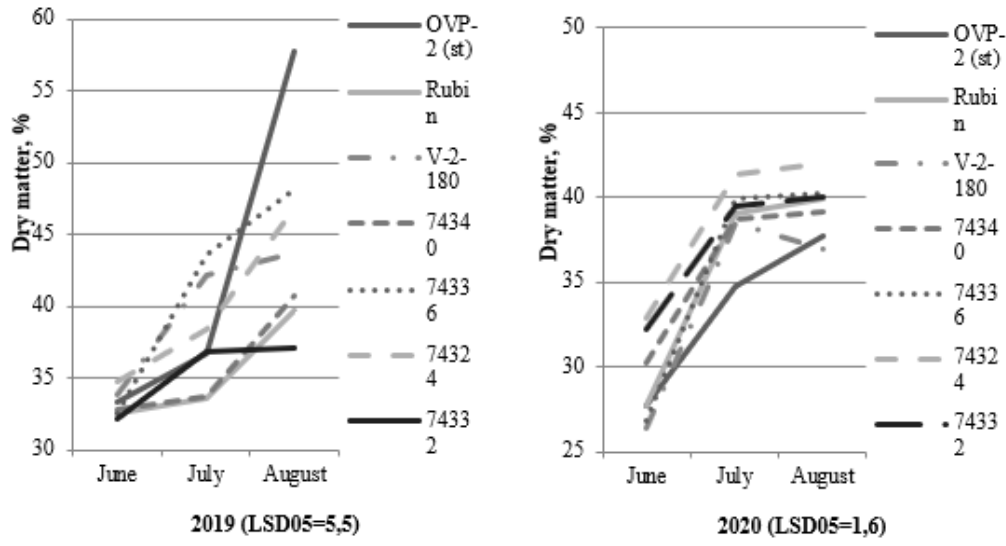

Fig. 3. Dynamics of dry matter accumulation in the leaves of scion-rootstock Novella combinations in the summer period, $\%$

When studying the influence of hydrothermal conditions in the summer period of 20192010, it was noted that water content of leaves is strongly correlated in the Novella variety on clonal rootstocks with the average daily air temperature $(r=0.99)$. At the same time, the 
correlation between leaf water content, the amount of precipitation and the HTC weakens ( $\mathrm{r}$ $=-0.24$ and -0.36$)$ (Table 2).

A direct correlation $(r=0.76)$ was established between leaves water deficit and average daily air temperature. The water deficit is inversely correlated with the amount of precipitation $(\mathrm{r}=-0.77)$ and HTC $(\mathrm{r}=-0.83)$ (Table 2).

A close correlation was determined between dry matter content in leaves of the Novella variety on clonal rootstocks and average daily air temperature $(r=-0.99)$. The correlation between the dry matter content in leaves, the amount of precipitation and the HTC was weak $(r=0.26$ and 0.35$)$ (Table 2$)$.

Table 2. Pair correlation coefficients (r) between the physiological parameters of the water regime of the Novella scion-rootstock combinations and the climatic factors of the summer period, 2019-2020.

\begin{tabular}{|l|l|l|l|}
\hline $\begin{array}{l}\text { Physiological } \\
\text { parameters }\end{array}$ & $\begin{array}{l}\text { Average daily air } \\
\text { temperature, }{ }^{\circ} \mathrm{C}\end{array}$ & $\begin{array}{l}\text { Precipitation amount, } \\
\mathrm{mm}\end{array}$ & HTC \\
\hline $\begin{array}{l}\text { Water content, } \\
\%\end{array}$ & $0.99^{*}$ & -0.24 & -0.36 \\
\hline $\begin{array}{l}\text { Water deficit, } \\
\%\end{array}$ & 0.76 & -0.77 & -0.83 \\
\hline Dry matter, \% & $-0.99^{*}$ & 0.26 & 0.35 \\
\hline
\end{tabular}

* Correlation is reliable at the $5 \%$ significance level

\section{Conclusions}

As a result of studying the water regime dynamics, general patterns of water exchange in cherry leaves were established. We found that during the ripening of the scion-rootstock combinations fruits, there was more dramatic decrease in the total water in the leaves than in other phases of cherry development. Water content steadily decreased by autumn, due to age-related changes in the leaves and strongly depended on the average daily air temperature. The decrease in water content in the Novella scion-rootstock combinations in August was accompanied by the maximum accumulation of dry matter in leaf tissues. The water deficit in the leaves depended on the hydrothermal regime of the summer period. The highest water deficiency indicator in leaves was found during shoots growth and formation of the leaf apparatus. The conducted studies suggested a better adaptation to the conditions of the summer period in the scion-rootstock combinations (Novella/Rubin, V-2-180, 74340, 74336, 74332), which, against the background of reduced hydration and dry matter accumulation, were characterized by the lowest water deficit in the leaves.

\section{References}

1. T. Inoue, S. Inanaga, Y. Sugimoto, P. An, A.E. Eneji, Photosynthetica, 42, 559 (2004)

2. T. Watanabe, T. Kume, Paddy Water Environment, 7, 313 (2009)

3. F. Shah, J. Huang, K. Cui, L. Nie, T. Shah, C. Chen, K. Wang, Journal of Agricultural Science, Cambridge, 149, 545 (2011)

4. M. Hasanuzzaman, M.A. Hossain Teixeira da Silva JA, M. Fujita, Crop Stress and its management: Perspectives and strategies, 261 (2012)

5. FAO Statistical yearbook 2013. World Food and Agriculture. Food and Agriculture Organization of the United Nations (2013) http://www.fao.org 
6. T.N. Doroshenko, N.V. Zakharchuk, D.V. Maximtsov, Resistance of fruit and ornamental plants to temperature stressors: diagnostics and ways to increase, 174 (2014)

7. E. Ulyanovskaya, I. Suprun, S. Tokmakov, Y. Ushakova, Fruit growing and viticulture of South Russia, 25(1), 11 (2014)

8. Tworkoski T., Fazio G., D.M. Glenn, Scientia Horticulturae, 204, 70 (2016)

9. A. Alizadeh, V. Alizade, L. Nassery, A. Eivazi, Technical Journal of Engineering and Applied Science, 1(3), 86 (2011)

10. N.I. Nenko, G.K. Kiseleva, E.V. Ulyanovskaya, E.K. Yablonskaya, A.V. Karavayeva1, Sel'skokhozyaistvennaya biologiya, 54(1), 158 (2019)

11. A. Wahid, S. Gelani, M. Ashraf, M. Foolad Environ, Exp. Bot., 61(3), 199 (2007)

12. E.S. Chentsova, Fruit growing, viticulture: autoref. cand. biol. sc. dis., 24 (2008)

13. M.D. Kushnirenko, Physiology of water exchange and drought resistance of fruit plants, 215 (1975)

14. V.G. Leonchenko, R.P. Evseeva, E.V. Zhbanova, T.A. Cherenkova, Preliminary selection of promising genotypes of fruit plants for ecological stability and biochemical value of fruits, 72 (2007)

15. P.S. Prudnikov, Z.E. Ozherelieva, Physiological and biochemical methods for diagnosing the resistance of fruit crops to drought and hyperthermia, 47 (2019)

16. T.N. Doroshenko, N.V. Zakharchuk, L.G. Riazanova, Adaptive potential of fruit plants in the South of Russia, 123 (2010)

17. N.I. Saveliev, A.N. Yushkov, N.N. Savelieva, A.S. Zemisov, V.V. Chivilev, R.E. Kirillov, M.Yu. Akimov, M.B. Gladysheva, Al.V. Kruzhkov, A.A. Konyukhova et al, Genetic potential of fruit crops resistance to abiotic stressors, 212 (2010)

18. C. Zhao, B. Liu, S. Piao, X. Wang, D. Lobell, Y. Huang, et al., Proceedings of the National Academy of Sciences of the United States of America, 114, 9326 (2017)

19. Z.E. Ozherelieva, N.G. Krasova, A.M. Galasheva, Contemporary horticulture, 1, 87 (2015)

20. H.J. De Boeck, S. Bassin, M. Verlinden, M. Zeiter, E. Hiltbrunner, New Phytologist, 209, $531(2015)$

21. S.I. Zandalinas, C. Sales, J. Beltrán, A. Gómez-Cadenas, V. Arbona, Frontiers in Plant Science, 7, 1954 (2017)

22. V. Rouhi, R. Samson, R. Lemeur, P. Damme, Environmental and Experimental Botany, 59, 117 (2007)

23. A. Yadollahi, K. Arzani, A. Ebadi, M. Wirthensohn S. Karimi, Scientia Horticulturae, 129(3), 403 (2011)

24. M.A. Solovieva, Winter hardiness of fruit crops in different growing conditions, 239 (1967) 